(C) The Author(s), 2021. Published by Cambridge University Press for the Arizona Board of Regents on behalf of the University of Arizona. This is an Open Access article, distributed under the terms of the Creative Commons Attribution licence (https://creativecommons.org/licenses/by/4.0/), which permits unrestricted re-use, distribution, and reproduction in any medium, provided the original work is properly cited.

\title{
RADIOCARBON IN GLOBAL TROPOSPHERIC CARBON DIOXIDE
}

\author{
Ingeborg Levin ${ }^{1 *(1)} \cdot$ Samuel Hammer ${ }^{1,2}$ - Bernd Kromer $^{1}(\mathbb{D}) \cdot$ Susanne Preunkert $^{3,2}$ (D) \\ Rolf Weller $^{4}$ (i) Douglas E Worthy ${ }^{5}$

\begin{abstract}
${ }^{1}$ Institut für Umweltphysik, Heidelberg University, Heidelberg, Germany
${ }^{2}$ ICOS Central Radiocarbon Laboratory, Heidelberg University, Heidelberg, Germany

${ }^{3}$ Université Grenoble Alpes, CNRS, Institut des Géosciences de l'Environnement (IGE), Grenoble, France

${ }^{4}$ Alfred-Wegener-Institut Helmholtz Zentrum für Polar- und Meeresforschung, Bremerhaven, Germany

${ }^{5}$ Environment and Climate Change Canada, Climate Research Division, Toronto, Ontario, Canada
\end{abstract}

\begin{abstract}
Since the 1950 s, observations of radiocarbon $\left({ }^{14} \mathrm{C}\right)$ in tropospheric carbon dioxide $\left(\mathrm{CO}_{2}\right)$ have been conducted in both hemispheres, documenting the so-called nuclear "bomb spike" and its transfer into the oceans and the terrestrial biosphere, the two compartments permanently exchanging carbon with the atmosphere. Results from the Heidelberg global network of $\Delta^{14} \mathrm{C}-\mathrm{CO}_{2}$ observations are revisited here with respect to the insights and quantitative constraints they provided on these carbon exchange fluxes. The recent development of global and hemispheric trends of $\Delta^{14} \mathrm{C}-\mathrm{CO}_{2}$ are further discussed in regard to their suitability to continue providing constraints for ${ }^{14} \mathrm{C}$-free fossil $\mathrm{CO}_{2}$ emission changes on the global and regional scale.
\end{abstract}

KEYWORDS: anthropogenic ${ }^{14} \mathrm{CO}_{2}$ perturbations, bomb radiocarbon, global carbon cycle, tropospheric ${ }^{14} \mathrm{CO}_{2}$ data.

\section{INTRODUCTION}

Atmospheric nuclear weapon testing in the 1950s and 1960s in the Northern Hemisphere was a period of great anxiety, however, it had significant side effects for environmental sciences in many aspects. The artificial production of more than $6 \times 10^{28}$ atoms or about 1.4 tons of radiocarbon $\left({ }^{14} \mathrm{C}\right.$ ) (Naegler and Levin 2006), lead to a doubling of the ${ }^{14} \mathrm{C} / \mathrm{C}$ ratio in tropospheric $\mathrm{CO}_{2}$ of the Northern Hemisphere with a prominent spike in 1963 (Nydal and Lövseth 1983; Levin et al. 1985). This "bomb spike" that reached the Southern Hemisphere with some delay (Manning et al. 1990), has been used as a transient tracer in all compartments of the fast carbon cycle (e.g., Broecker et al. 1985; Levin and Hesshaimer 2000; Trumbore 2009), but also to study atmospheric dynamics, such as inter-hemispheric (e.g., Münnich and Vogel 1958, 1963; Czeplak and Junge 1974) and stratospheretroposphere air mass exchange (e.g., Telegadas 1971; Hesshaimer and Levin 2000; Levin et al. 2010). As an indirect outcome of the weapon testing, a wealth of new insights into atmospheric and carbon cycle dynamics could be achieved in the decades following the nuclear test ban treaty in 1963.

Today, the transient bomb-radiocarbon signal has levelled off, and the anthropogenic input of radiocarbon-free fossil $\mathrm{CO}_{2}$ into the atmosphere has become the dominant driver of the decrease of the ${ }^{14} \mathrm{C} / \mathrm{C}$ ratio in global atmospheric $\mathrm{CO}_{2}$ (Levin et al. 2010; Graven 2015). This ${ }^{14} \mathrm{CO}_{2}$-free anthropogenic $\mathrm{CO}_{2}$ flux from the burning of fossil fuels and cement production has increased globally by more than fourfold compared to the $1960 \mathrm{~s}$, and, together with ongoing land-use changes, has resulted in an increase of the atmospheric $\mathrm{CO}_{2}$ burden by more than $5 \mathrm{PgC}\left(1 \mathrm{PgC}=10^{15} \mathrm{gC}\right)$ or $>0.5 \%$ per year in the last decade (Friedlingstein et al. 2020). The fossil $\mathrm{CO}_{2}$ emissions are not evenly distributed over the globe and because the biosphere and oceans today, in most regions, are sources of bomb

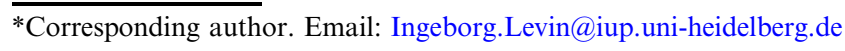




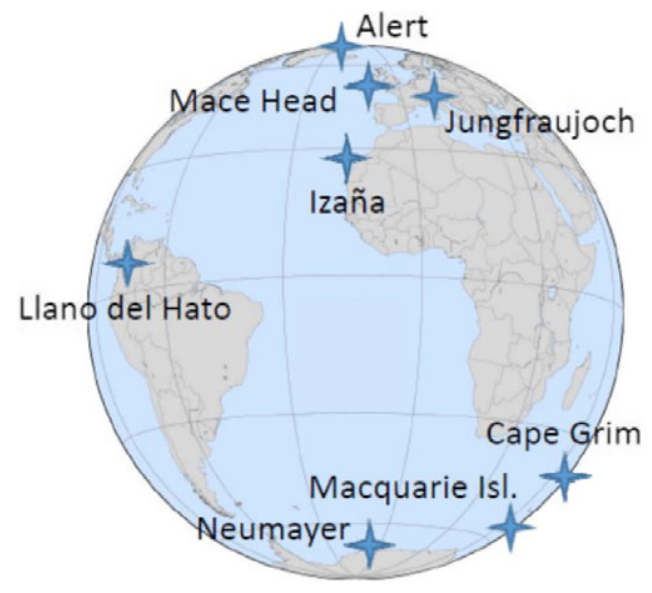

Figure 1 Cooperative $\mathrm{CO}_{2}$ background air sampling network for high-precision ${ }^{14} \mathrm{C}$ analysis in the Heidelberg Radiocarbon laboratory.

${ }^{14} \mathrm{CO}_{2}$, the distribution of tropospheric $\Delta^{14} \mathrm{C}-\mathrm{CO}_{2}$ has undergone significant changes since the 2000s.

After a brief overview on the development in the last $60+$ years of ${ }^{14} \mathrm{C}$ in tropospheric $\mathrm{CO}_{2}$, this paper reviews the insights from earlier studies that used bomb ${ }^{14} \mathrm{C}$ for carbon cycle budgeting. Further, we present our extended high-precision $\Delta^{14} \mathrm{C}-\mathrm{CO}_{2}$ observations in background air at Alert, Jungfraujoch, Izaña, Cape Grim, Macquarie Island and the German Antarctic Neumayer station (Figure 1), and discuss these data in view of their potential to serve as additional constraints for global carbon fluxes. Finally, we provide a perspective on how ongoing changes of the distribution and trends of $\triangle^{14} \mathrm{C}-\mathrm{CO}_{2}$ in the background troposphere could potentially be used to constrain major components of the carbon cycle, including monitoring of anthropogenic $\mathrm{CO}_{2}$ emission and their reductions in view of the Paris agreement from the regional to the global scale.

\section{THE HISTORY OF ATMOSPHERIC $\Delta^{14} \mathrm{C}-\mathrm{CO}_{2}$ OBSERVATIONS}

Shortly after Anderson and Libby (1951) published their first measurements of natural radiocarbon in various compartments of the Earth system, a number of Radiocarbon Laboratories have been established world-wide. First measurements of $\triangle^{14} \mathrm{C}_{-} \mathrm{CO}_{2}$ in background air were conducted in 1954 in the Southern Hemisphere with sampling on the south-western coast of the Northern Island of New Zealand (NZ) close to Wellington $\left(41.25^{\circ} \mathrm{S}, 174.69^{\circ} \mathrm{E}, 300 \mathrm{~m}\right.$ asl; Rafter and Fergusson 1957). Münnich and Vogel (1963) collected their first atmospheric $\mathrm{CO}_{2}$ samples for ${ }^{14} \mathrm{C}$ analysis in 1959 at a number of stations in the Northern and Southern Hemisphere. Quasi-continuous sampling was finally established at Vermunt in the Austrian Alps $\left(47.07^{\circ} \mathrm{N}, 9.57^{\circ} \mathrm{E}, 1800 \mathrm{~m}\right.$ asl; Levin et al. 1985). In the early years, all samples were collected by passive absorption of atmospheric $\mathrm{CO}_{2}$ in sodium hydroxide solution. $\mathrm{CO}_{2}$ was then extracted in the laboratory from this basic solution by acidification. After purification of the extracted $\mathrm{CO}_{2}$ the samples were analyzed by gas proportional counting (Kromer and Münnich 1992; Turnbull et al. 2017). 
In the 1970s, advancements in both the sampling and analysis systems occurred, e.g. the Heidelberg sampling system at Vermunt station was changed to actively flushing air through a rotating absorption column, now allowing quantitative (less fractionated) sampling of $\mathrm{CO}_{2}$ over a well-defined time interval (Levin et al. 1980). At the NZ station, in addition to passive sampling, whole air flask samples started to be collected, and ${ }^{14} \mathrm{C}$ analysis changed from gas counting to Accelerator Mass Spectrometric analysis (for details, see Turnbull et al. 2017, supplementary material). While in Heidelberg measurement of background air samples was and still is today by gas proportional counting, we changed our European background monitoring site in the Alps from Vermunt in Austria to Jungfraujoch in Switzerland $\left(46.55^{\circ} \mathrm{N}, 7.98^{\circ} \mathrm{E}, 3450 \mathrm{~m}\right.$ asl) in 1986. This seemed advantageous as the high elevation of Jungfraujoch provides better access to free tropospheric air. In addition, several continuous measurements of other atmospheric trace substances, including $\mathrm{CO}_{2}$, are conducted at this site (Forrer et al. 2000).

The two pioneer stations in New Zealand and in the Austrian Alps, which document the largest excursions of bomb ${ }^{14} \mathrm{CO}_{2}$ in the Southern and the Northern Hemisphere troposphere, were supplemented by an increasing number of $\Delta^{14} \mathrm{C}-\mathrm{CO}_{2}$ observations world-wide, including the tropics and sub-tropics. The most comprehensive records were published by Nydal and Lövseth (1983, 1996) and by Meijer et al. (1995). These globally distributed data sets provided the opportunity to track the bomb ${ }^{14} \mathrm{CO}_{2}$ spike throughout the entire troposphere. Unfortunately, most of these sampling efforts were discontinued in the 1980s after bomb ${ }^{14} \mathrm{CO}_{2}$ had become well-mixed in both hemispheres.

Starting in 1983, when the German Antarctic Neumayer station became operational in Dronning Maud Land at the Antarctic coast $\left(70.65^{\circ} \mathrm{S}, 8.25^{\circ} \mathrm{E}, 17 \mathrm{~m}\right.$ asl), the Heidelberg Radiocarbon laboratory was granted the opportunity to start $\mathrm{CO}_{2}$ sampling for ${ }^{14} \mathrm{C}$ analysis at this remote Antarctic site. Soon after the first data became available, it was realized that the $\Delta^{14} \mathrm{C}-\mathrm{CO}_{2}$ level at Neumayer station was significantly influenced by a ${ }^{14} \mathrm{CO}_{2}$ disequilibrium flux with the Antarctic circumpolar surface water, originating from upwelling of about 800-year-old intermediate water of the Pacific Ocean, which, due to its age, is strongly depleted in (natural) ${ }^{14} \mathrm{C}$ (Levin et al. 1987). This exciting feature of lower $\triangle{ }^{14} \mathrm{C}-\mathrm{CO}_{2}$ levels in atmospheric $\mathrm{CO}_{2}$ of Southern Hemisphere air when compared to the Northern Hemisphere had already been observed by Lerman et al. (1970) on tree rings. Their results were now confirmed by direct atmospheric observations. For us, this finding was the catalyst to re-start global monitoring of $\Delta^{14} \mathrm{C}-\mathrm{CO}_{2}$ in the atmosphere, i.e. during a period when other research agencies were terminating their ${ }^{14} \mathrm{CO}_{2}$ monitoring efforts. The potential of $\Delta^{14} \mathrm{C}-\mathrm{CO}_{2}$ observations as an ongoing constraint of gross carbon exchange fluxes between atmosphere, ocean and biosphere seemed obvious. However, unlike the situation immediately after the test ban treaty in 1963, being 20 years later, the spatial gradients and temporal variations of $\Delta^{14} \mathrm{C}-\mathrm{CO}_{2}$ in the atmosphere were more than two orders of magnitude smaller. To detect such small signals required increased precision in $\Delta{ }^{14} \mathrm{C}-\mathrm{CO}_{2}$ analysis (about $2 \%$ ), and could only be achieved by gas proportional counting at that time. In the $1980 \mathrm{~s}$, we begun establishing a new network of $\Delta^{14} \mathrm{C}-\mathrm{CO}_{2}$ observations at a number of globally distributed stations, in cooperation with colleagues operating the Global Atmosphere Watch stations for continuous greenhouse gases observations (see map in Figure 1). Other investigations (Hesshaimer et al. 1994; Levin and Hesshaimer 2000), were also carried out using these data to close the atmospheric bomb ${ }^{14} \mathrm{C}$ budget, and, in turn, determine the total input of anthropogenic ${ }^{14} \mathrm{C}$ into the global carbon system (Naegler and Levin 2006). 


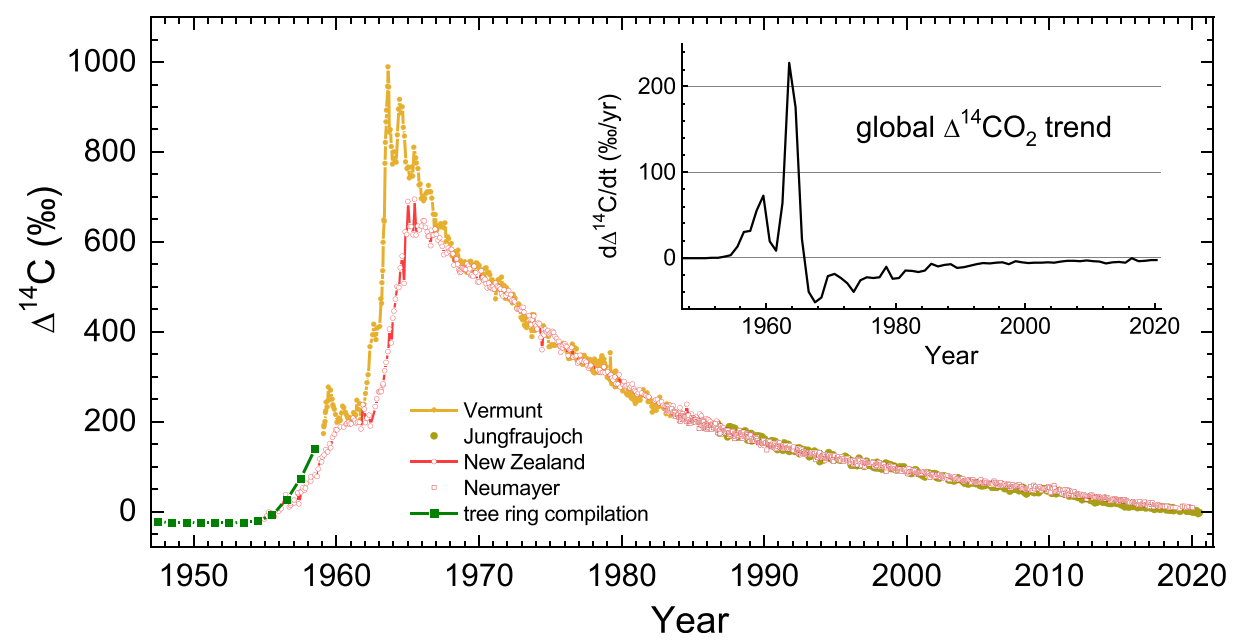

Figure 2 Development of tropospheric $\Delta^{14} \mathrm{C}-\mathrm{CO}_{2}$ in both hemispheres since the start of the atmospheric nuclear bomb tests. New Zealand data are from Turnbull et al. (2017). The inlay shows the derivative of annual mean $\Delta^{14} \mathrm{C}-\mathrm{CO}_{2}$.

In the 2000s, the Scripps Institution of Oceanography (SIO) started analyzing ${ }^{14} \mathrm{C}$ on $\mathrm{CO}_{2}$ extracted from flask samples collected from their global network of stations along the Pacific Ocean, stretching from Barrow, Alaska, down to the South Pole (Graven et al. 2012). These samples were analyzed with high precision Accelerator Mass Spectrometry. The data were included in a global atmospheric transport model (TM3, Heimann and Korner 2003) to investigate the spatial $\Delta^{14} \mathrm{C}-\mathrm{CO}_{2}$ distribution and document its changes since the 1990s. Unfortunately, $\Delta^{14} \mathrm{C}-\mathrm{CO}_{2}$ results from the SIO network since 2007 have not been published. In the 2000s, the Institute of Arctic and Alpine Research (INSTAAR) began measuring $\triangle^{14} \mathrm{C}-\mathrm{CO}_{2}$ on flask samples from the Global Monitoring Laboratory (GML) of the National Oceanic and Atmospheric Administration (NOAA/GML), primarily from aircraft flights and ground-based locations over North America (Turnbull et al. 2006; Miller et al. 2012). The primary focus of the INSTAAR program was to use these data to partition the ${ }^{14} \mathrm{C}$-free fossil from the biogenic $\mathrm{CO}_{2}$ component over the continent (Miller et al. 2012; Basu et al. 2020). $\Delta^{14} \mathrm{C}-\mathrm{CO}_{2}$ observations over continents have become the main focus of the carbon cycle community today, as ${ }^{14} \mathrm{C}$ is the most direct tracer to quantify the regional fossil $\mathrm{CO}_{2}$ component (Levin et al. 2003; Turnbull et al. 2017; Graven et al. 2009). Also, in Europe, a new network of $\Delta^{14} \mathrm{C}-\mathrm{CO}_{2}$ monitoring stations was established as part of the atmospheric observational network of the Integrated Carbon Observation System (ICOS) Research Infrastructure (Levin et al. 2020). Since 2018 Jungfraujoch station has officially become part of this network, and the ${ }^{14} \mathrm{C}-\mathrm{CO}_{2}$ analyses are conducted by the ICOS Central Radiocarbon Laboratory in Heidelberg (https://www. iup.uni-heidelberg.de/research/kk/icos).

\section{TEMPORAL DEVELOPMENT OF $\Delta^{\mathbf{1 4}} \mathrm{C}-\mathrm{CO}_{2}$ IN THE GLOBAL TROPOSPHERE}

The long-term development of $\Delta^{14} \mathrm{C}$ in tropospheric $\mathrm{CO}_{2}$ in both hemispheres is displayed in Figure 2. The increase in the Southern Hemisphere ( $\mathrm{SH}$ ) since 1954 is documented by data from the New Zealand site close to Wellington (Turnbull et al. 2017). From 1983 onwards, we extended this record with data from the Neumayer station, Antarctica (Levin and Hammer 
2021). In the Northern Hemisphere (NH) atmospheric, background observations are only available from 1959 onwards. In Figure 2 we extend the NH record back to the 1940s using annual mean values for $30^{\circ}-90^{\circ} \mathrm{N}$ from the compilation by Graven et al. (2017), based on tree ring analyses. The Vermunt record ended in 1985 when our Alpine background sampling site was moved to the Jungfraujoch station. For all stations, the results from individual atmospheric samples are shown in Figure 2. The data are available at the ICOS-ERIC Carbon Portal (Levin and Hammer 2021).

In the NH record, regular seasonal variations are clearly visible in the years of 1963-1968. This seasonality is caused by spring-time intrusion of stratospheric air into the troposphere (Telegadas 1971). During these initial years after the nuclear test ban treaty in 1963, a large share of bomb-produced ${ }^{14} \mathrm{CO}_{2}$ continued to reside in the stratosphere, which, in the course of the following years, was transported into the troposphere, mainly during spring (Tans 1981; Hesshaimer and Levin 2000). The subsequent transport of bomb ${ }^{14} \mathrm{CO}_{2}$ from the $\mathrm{NH}$ troposphere into the $\mathrm{SH}$ then caused a decrease of $\Delta^{14} \mathrm{C}-\mathrm{CO}_{2}$ in late summer. However, the approximately 1.5 years shift between Northern and Southern Hemisphere ${ }^{14} \mathrm{C}-\mathrm{CO}_{2}$ curves provides the most direct measure of the interhemispheric exchange time. This atmospheric $\Delta^{14} \mathrm{C}-\mathrm{CO}_{2}$ dynamic during and shortly after the bomb tests has been used to calibrate or evaluate the validity of transport in atmospheric circulation models (e.g., Johnston 1989; Kjellström et al. 2000; Levin et al. 2010).

The inlay of Figure 2 shows the year-to-year change of global mean $\Delta^{14} \mathrm{C}-\mathrm{CO}_{2}$ values, calculated from the global compilation of Graven et al. (2017), extended with the most recent Heidelberg measurements from the $\mathrm{NH}$ and the $\mathrm{SH}$. Unfortunately, no recent data from the tropics are available to calculate annual global means. We therefore extrapolated the tropical record with the annual mean trends observed in 2015-2020 for the extratropical latitudes. After the steep increase of tropospheric $\Delta^{14} \mathrm{C}-\mathrm{CO}_{2}$, reaching a maximum in the $\mathrm{NH}$ in 1963 and in the SH about 1.5 years later, we observe a fast decrease in both hemispheres. This decrease is caused by equilibration of the atmospheric bomb ${ }^{14} \mathrm{C}$ disturbance with reservoirs exchanging $\mathrm{CO}_{2}$ with the atmosphere, namely the ocean and the terrestrial biosphere. According to Levin et al. (2010: Figure 7) the largest net uptake of bomb ${ }^{14} \mathrm{C}$ by the world oceans occurred in the 1970 s and was about twice as high when compared to the net uptake by the biosphere. While the terrestrial biosphere acted as a net sink of anthropogenic ${ }^{14} \mathrm{C}$ only until the 1980s (Naegler and Levin 2009), the oceans continued to be a sink of bomb ${ }^{14} \mathrm{C}$ until around 2010 .

Starting in the mid-1990s, fossil $\mathrm{CO}_{2}$ emissions into the global atmosphere became the dominant contribution to the decreasing global $\Delta{ }^{14} \mathrm{C}-\mathrm{CO}_{2}$ trend. Levin et al. (2010) attempted to use the global ${ }^{14} \mathrm{C}-\mathrm{CO}_{2}$ trend of the last decades as an independent constraint for the global fossil $\mathrm{CO}_{2}$ emissions into the atmosphere. However, the uncertainty estimates were determined to be too large $(25-30 \%)$ to be useful, due to the large uncertainties in the partitioned contributions from ocean and biosphere exchange fluxes to the $\Delta^{14} \mathrm{C}-\mathrm{CO}_{2}$ trend, compared to the global bottom-up fossil emission estimates, which were estimated to better than $\pm 10 \%$ (Gilfillan and Marland 2021). Today though, with improved information on ocean and biosphere ${ }^{14} \mathrm{CO}_{2}$ fluxes, it may be a useful endeavor to repeat this exercise. However, for this purpose we would first need more representative high precision $\Delta^{14} \mathrm{C}-\mathrm{CO}_{2}$ observations at background stations that are compatible to better than $\pm 0.5 \%$, in order to determine reliable global trends and hemispheric gradients, which today are only a few \%o (see Figure 3). Better knowledge on 

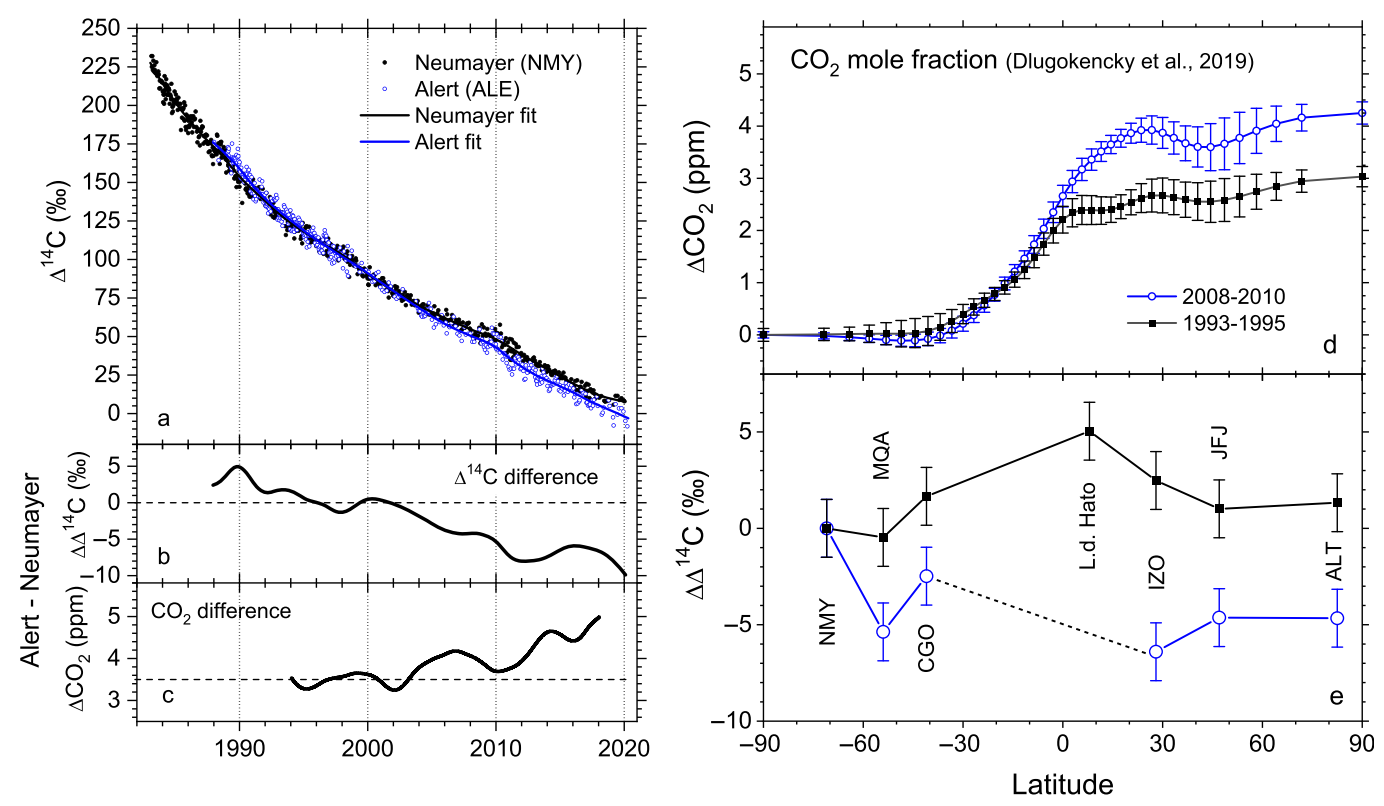

Figure 3 a: Long-term trend of $\Delta^{14} \mathrm{C}-\mathrm{CO}_{2}$ at the two polar stations Alert (Arctic) and Neumayer (Antarctica) (Levin and Hammer 2021). The solid lines are de-seasonalised fitted curves through the individual data. Panel b displays the difference between both fitted $\Delta^{14} \mathrm{C}-\mathrm{CO}_{2}$ curves, while $\mathrm{c}$ shows the differences of corresponding fitted curves through $\mathrm{CO}_{2}$ concentration data from flask samples collected at the two stations (Weller et al. 2007; Worthy et al. 2021). d: Meridional distribution of three-year averages of $\mathrm{CO}_{2}$ (Dlugokencky et al. 2019), and $\Delta^{14} \mathrm{C}-\mathrm{CO}_{2}$ (e) for $1993-1995$ in comparison to 2008-2010.

compatibility can only be achieved through frequent intercomparisons between those labs that contribute to this global $\Delta^{14} \mathrm{C}-\mathrm{CO}_{2}$ background monitoring network. An earlier intercomparison between our low-level counting laboratory in Heidelberg (ICOS CRL) and 8 AMS laboratories yielded an overall agreement of better that $\pm 0.5 \%$, but it was not conclusive concerning the compatibility within the AMS laboratories themselves (Hammer et al. 2017). More frequent regular intercomparisons are therefore urgently needed to achieve an overall compatibility of better than $\pm 0.5 \%$. Then ${ }^{14} \mathrm{C}$-based $\mathrm{ffCO}_{2}$ estimates could provide an excellent independent top-down check on the global stocktake of the Paris Climate Accord (UNFCCC 2015).

\section{SPATIAL VARIATION OF $\Delta{ }^{14} \mathrm{C}-\mathrm{CO}_{2}$ IN THE TROPOSPHERE}

Because the bulk of the fossil $\mathrm{CO}_{2}$ emissions are released in the $\mathrm{NH}$, observed $\mathrm{CO}_{2}$ concentrations in the Northern are higher than in the Southern Hemisphere (Dlugokencky et al. 2019). However, until the end of the last century, the north-south difference of $\Delta^{14} \mathrm{C}$ $\mathrm{CO}_{2}$ was counterintuitively positive, with higher $\Delta^{14} \mathrm{C}-\mathrm{CO}_{2}$ being observed in the North than in the South (Levin and Hesshaimer 2000). This latter north-south difference was caused by a strong ${ }^{14} \mathrm{CO}_{2}$ disequilibrium flux with the $\Delta{ }^{14} \mathrm{C}$-depleted surface water of the Southern Ocean around Antarctica (Levin et al. 1987). The sign of the observed northsouth difference, however, changed in the mid-2000s, with lower $\Delta^{14} \mathrm{C}-\mathrm{CO}_{2}$ being observed at high northern latitudes such as at Alert in the Arctic $\left(82.45^{\circ} \mathrm{N}, 62.52^{\circ} \mathrm{W}, 185 \mathrm{~m}\right.$ asl) 
when compared to Neumayer, Antarctica. We calculated smoothed fitted curves (Nakazawa et al. 1997) through the individual data from the two polar stations and plot the long-term trends together with the individual data in Figure 3a. The difference between the two curves, fitting Alert and Neumayer $\Delta^{14} \mathrm{C}-\mathrm{CO}_{2}$ data, is shown in Figure $3 \mathrm{~b}$. It can be clearly seen that while the $\Delta^{14} \mathrm{C}-\mathrm{CO}_{2}$ difference was positive until the end of the $1990 \mathrm{~s}$, it decreased to about zero at the turn of the century and around 2003, it changed to negative values and continues in this manner until today. At the same time, the $\mathrm{CO}_{2}$ concentration difference between the two polar stations increased from ca. $3.5 \mathrm{ppm}$ in the 1990s to ca. 4-5 ppm in the last decade (Figure 3c).

The observed change in the sign in the north-south $\Delta^{14} \mathrm{C}-\mathrm{CO}_{2}$ difference has been previously reported by Graven et al. (2012). There are two reasons that may have caused this reversal: (1) The increase of the north-south gradient of $\mathrm{CO}_{2}$ due to increasing fossil $\mathrm{CO}_{2}$ emissions being more dominant in the $\mathrm{NH}$, and in turn, causing an increasing dilution of the ${ }^{14} \mathrm{C} / \mathrm{C}$ ratio in $\mathrm{NH}$ $\mathrm{CO}_{2}$, and (2) the decrease of the $\Delta^{14} \mathrm{C}-\mathrm{CO}_{2}$ disequilibrium between the atmosphere and surface waters in the circum Antarctic ocean (Graven et al. 2012). While the difference between atmospheric and surface ocean $\Delta^{14} \mathrm{C}-\mathrm{CO}_{2}$ in the late 1980 and 1990 s was still about 200 $300 \%$, it decreased by about $150 \%$ in the following decade, because atmospheric $\Delta^{14} \mathrm{C}$ $\mathrm{CO}_{2}$ decreased by this amount (Figure 2). If we assume that the increase of $\mathrm{CO}_{2}$ difference from about 1994 to 2009 between Northern and Southern Hemisphere of about $1.5 \mathrm{ppm}$ was caused by ${ }^{14} \mathrm{C}$-free fossil $\mathrm{CO}_{2}$ alone, this would have caused a change in the $\Delta^{14} \mathrm{C}-\mathrm{CO}_{2}$ north-south difference of approximately 3\%o. The remaining difference of more than $2 \% 0$ must therefore be due to other reasons. The right panels of Figure 3 show the mean meridional distributions of $\mathrm{CO}_{2}$ concentration (d) and $\Delta^{14} \mathrm{C}_{-} \mathrm{CO}_{2}$ (e) in the period of 1993-1995 compared to the 15 years later period of $2008-2010$. The change in $\Delta^{14} \mathrm{C}-\mathrm{CO}_{2}$ relative to Neumayer (NMY) station and $\mathrm{CO}_{2}$ concentration relative to South Pole is observed throughout the Northern Hemispheric sites. $\mathrm{CO}_{2}$ and $\Delta^{14} \mathrm{C}-\mathrm{CO}_{2}$ are rather homogeneously distributed from polar regions (Alert) to the subtropics at Izaña (Tenerife Island, $28.3^{\circ} \mathrm{N}, 16.48^{\circ} \mathrm{W}, 2373 \mathrm{~m}$ asl) with variations smaller than $1.5 \%$ in $\Delta^{14} \mathrm{C}-\mathrm{CO}_{2}$ and $1 \mathrm{ppm}$ in $\mathrm{CO}_{2}$. In contrast, corresponding latitudes of the Southern Hemisphere show a significant $\Delta^{14} \mathrm{C}-\mathrm{CO}_{2}$ dip at Macquarie Island $\left(54.5^{\circ} \mathrm{S}, 158.97^{\circ} \mathrm{E}, 6 \mathrm{~m}\right.$ asl), which is not accompanied by a significant variation in $\mathrm{CO}_{2}$ concentration. In this region of the Southern Ocean around Macquarie Island (MQA) with depleted $\Delta^{14} \mathrm{C}$ the ${ }^{14} \mathrm{CO}_{2}$ disequilibrium flux is largest, also because large wind velocities enhance air-sea gas exchange.

As is the case for the long-term trend, changes in the north-south $\Delta^{14} \mathrm{C}-\mathrm{CO}_{2}$ difference can also provide a constraint on the predominantly Northern Hemispheric fossil $\mathrm{CO}_{2}$ emissions. But keeping in mind that there are uncertainties in the other components contributing to the meridional $\Delta^{14} \mathrm{C}-\mathrm{CO}_{2}$ difference as well as uncertainties associated in atmospheric model transport limits the uncertainty of the fossil emissions constraint to around $25-30 \%$ (Levin et al. 2010).

A special feature can be seen in the data of the tropical station Llano del Hato (Venezuela, $8.78^{\circ} \mathrm{N} 70.87^{\circ} \mathrm{W}, 3600 \mathrm{~m}$ asl). Here we observed a regional $\Delta^{14} \mathrm{C}-\mathrm{CO}_{2}$ maximum in the 1990 s, which we attributed to a signal of net bomb ${ }^{14} \mathrm{CO}_{2}$ released by heterotrophic respiration from the tropical biosphere. Naegler and Levin (2009) calculated from their global bomb- ${ }^{14} \mathrm{C}$ budget that the global biosphere switched from a net sink of anthropogenic ${ }^{14} \mathrm{CO}_{2}$ to a net source to the atmosphere around the 1980s. Small fossil $\mathrm{CO}_{2}$ emissions or atmosphere ocean disequilibrium fluxes could be the reason why this 
bomb- ${ }^{14} \mathrm{C}$ signal from the biosphere is visible at these latitudes. Unfortunately, due to logistics problems, sampling at this important tropical site was terminated in 1997. Graven et al. (2012) also found about 3-6\% higher $\Delta^{14} \mathrm{C}-\mathrm{CO}_{2}$ in $2005-2007$ at two tropical stations in the Pacific Ocean when compared to mid-latitude sites in the NH. Continuing observations in the tropics could possibly provide independent constraints on the turnover times of carbon in the terrestrial biosphere, an important parameter to assess the sustainability of the currently observed net uptake of anthropogenic $\mathrm{CO}_{2}$ emissions by the terrestrial biosphere.

\section{CONCLUSIONS AND PERSPECTIVES}

$\Delta^{14} \mathrm{C}-\mathrm{CO}_{2}$ in the troposphere over the last $60+$ years serves as an excellent transient tracer to study atmospheric and global carbon cycle dynamics. However, despite the wealth of information that is buried in the observed global distribution and trend of $\Delta^{14} \mathrm{C}-\mathrm{CO}_{2}$, only the first few decades of the existing records have yet been used to constrain global and regional exchange fluxes between the main compartments of the carbon cycle. This may be due to the sparsity of representative observations, for example, in the very heterogeneous terrestrial biosphere. But also for the much more homogenous global oceans, representative continuous monitoring of ${ }^{14} \mathrm{C}$ is incomplete. Further, only in the last decade, has ${ }^{14} \mathrm{C}$ been fully implemented in global models such as in the National Center for Atmospheric Research Community Earth System model (Koven et al. 2013; Jahn et al. 2015). Concerning atmospheric tracer transport modeling of $\mathrm{CO}_{2}$, including ${ }^{14} \mathrm{C}$ in global and regional inversions is still at its infancy (e.g., Turnbull et al. 2009; Basu et al. 2020). Here, not only do the ocean and biosphere "boundary conditions" need to be well defined, but reliable atmospheric modeling of ${ }^{14} \mathrm{CO}_{2}$ also requires stratosphere-troposphere air mass exchange to be represented correctly in the model. Contrary to the stable isotopes in $\mathrm{CO}_{2}$, where the tropospheric variability is governed by sources and sinks located at the Earth surface, the ${ }^{14} \mathrm{CO}_{2}$ cycle has a natural production source in the upper troposphere and lower stratosphere. All these challenges need to be accounted for in order to disentangle the small gradients and trends, particularly those observed in the last decade. However, most important are long-term high-precision measurements at key stations themselves. Models can always be improved in the future, but the atmosphere at present can only be sampled today.

\section{ACKNOWLEDGMENTS}

This work would not have been possible without the dedicated efforts and long-term support by the staff at the globally distributed sampling sites, as well as the technical personnel in the Heidelberg Radiocarbon laboratories. We wish to thank Ed Dlugokencky and Pieter Tans for providing $\mathrm{CO}_{2}$ meridional profile data from their global monitoring network. Macquarie Island sampling was supported by the Australian Antarctic Program, Cape Grim sampling by the Australian Bureau of Meteorology, Izaña sampling by the Agencia Estatal de Meteorología, Spain, and Jungfraujoch sampling by the Internationale Stiftung Hochalpine Forschungsstationen Jungfraujoch und Gornergrat. Our long-term monitoring was financially supported by a number of agencies in Germany and Europe, namely the Heidelberg Academy of Sciences, the Ministry of Education and Science, BadenWürttemberg, Germany, the German Science Foundation, the German Federal Ministries for the Environment, Nature Conservation and Nuclear Safety, for Education and Research, and for Transport and Digital Infrastructure as well as by the European Commission, Brussels, and the ICOS Research Infrastructure. 


\section{DATA AVAILABILITY}

Individual $\triangle^{14} \mathrm{C}-\mathrm{CO}_{2}$ data from Alert, Jungfraujoch, and Neumayer stations are available at the ICOS-ERC Carbon Portal (Levin and Hammer 2021).

\section{REFERENCES}

Anderson EC, Libby WF. 1951. World-wide distribution of natural radiocarbon. The Physical Review 81(1):64-69.

Basu S, Lehman SJ, Miller JB, Andrews AE, Sweeney C, Gurney KR, Xue X, Southon J, Tans PP. 2020. Estimating US fossil fuel $\mathrm{CO}_{2}$ emissions from measurements of ${ }^{14} \mathrm{C}$ in atmospheric $\mathrm{CO}_{2}$, PNAS 117(24):13300-13307. doi: 10.1073/pnas. 1919032117.

Broecker WS, Peng TH, Östlund G, Stuiver M. 1985. The distribution of bomb radiocarbon in the ocean. J. Geophys. Res. 90(C4):6953-6970. doi: 10.1029/JC090iC04p06953.

Czeplak G, Junge C. 1974. Studies of interhemispheric exchange in the troposphere by a diffusion model. Adv. Geophys. 18:57-72.

Dlugokencky EJ, Thoning KW, Lang PM, Tans PP. 2019. NOAA Greenhouse gas reference from atmospheric carbon dioxide dry air mole fractions from the NOAA ESRL Carbon Cycle Cooperative Global Air Sampling Data ftp:// aftp.cmdl.noaa.gov/data/trace_gases/co2/flask/ surface/Network. Last accessed 8.5.2021.

Forrer J, Rüttimann R, Schneiter D, Fischer A, Buchmann B, Hofer P. 2000. Variability of trace gases at the high-Alpine site Jungfraujoch caused by meteorological transport processes, J. Geophys. Res. 105:12241-12251. https://doi: 10.1029/1999JD901178.

Friedlingstein P, O'Sullivan M, Jones MW, Andrew RM, Hauck J, Olsen A, Peters GP, Peters W, Pongratz J, Sitch S, et al. 2020. Global carbon budget 2020. Earth Syst. Sci. Data 12: 3269-3340. doi: 10.5194/essd-12-3269-2020.

Gilfillan D, Marland G. 2021. CDIAC-FF: global and national $\mathrm{CO}_{2}$ emissions from fossil fuel combustion and cement manufacture: 1751-2017. Earth Syst. Sci. Data 13:1667-1680. doi: 10.5194/essd-13-1667-2021.

Graven HD. 2015. Impact of fossil fuel emissions on atmospheric radiocarbon and various applications of radiocarbon over this century. Proceedings of the National Academy of Sciences 112:9542-9545. doi: 10.1073/pnas.1504467112.

Graven HD, Allison CE, Etheridge DM, Hammer S, Keeling RF, Levin I, Meijer HAJ, Rubino M, Tans PP, Trudinger CM, Vaughn BH, White JWC. 2017. Compiled records of carbon isotopes in atmospheric $\mathrm{CO}_{2}$ for historical simulations in CMIP6. Geoscientific Model Development 10(12):4405-4417. doi: 10.5194/gmd-10-44052017.
Graven HD, Guilderson TP, Keeling RF. 2012. Observations of radiocarbon in $\mathrm{CO}_{2}$ at seven global sampling sites in the Scripps flask network: Analysis of spatial gradients and seasonal cycles. J. Geophys. Res. 117(D02303). doi: 10.1029/ 2011JD016535.

Graven HD, Stephens BB, Guilderson TB, Campos TL, Schimel DS, Campbell JE, Keeling RF. 2009. Vertical profiles of biospheric and fossil fuel-derived $\mathrm{CO}_{2}$ and fossil fuel $\mathrm{CO}_{2}$ : $\mathrm{CO}$ ratios from airborne measurements of ${ }^{14} \mathrm{C}, \mathrm{CO}_{2}$ and CO above Colorado, USA. Tellus B 61: 536-546. doi: 10.1111/j.1600-0889.2009.00421.x.

Hammer S, Friedrich R, Kromer B, Cherkinsky A, Lehman SJ, Meijer HA, Nakamura T, Palonen V, Reimer RW, Smith AM, Southon JR, Szidat S, Turnbull J, Uchida M. 2017. Compatibility of atmospheric ${ }^{14} \mathrm{CO}_{2}$ measurements: comparing the Heidelberg low-level counting facility to international accelerator mass spectrometry (AMS) laboratories. Radiocarbon 59(3):875-883. doi: 10. 1017/RDC.2016.62.

Heimann M, Korner S. 2003. The Global Atmospheric Tracer Model TM3. Model description and users manual release 3.8a. Tech. Rep. 5. Max Planck Inst. for Biogeochem., Jena, Germany.

Hesshaimer V, Heimann M, Levin I. 1994. Radiocarbon evidence for a smaller oceanic carbon dioxide sink than previously believed. Nature 370:201-203. doi: 10.1038/370201a0.

Hesshaimer V, Levin I. 2000. Revision of the stratospheric bomb ${ }^{14} \mathrm{CO}_{2}$ inventory. J. Geophys. Res. 105(D9):11,641-11,658.

Jahn A, Lindsay K, Giraud X, Gruber N, Otto-Bliesner BL, Liu Z, Brady EC. 2015. Carbon isotopes in the ocean model of the Community Earth System Model (CESM1). Geoscientific Model Development 985 8: 2419-2434. doi: 10.5194/gmd-8-2419-2015.

Johnston HS. 1989. Evaluation of excess carbon-14 and strontium-90 data for suitability to test two-dimensional stratospheric models. J. Geophys. Res. 94:18 485-18 493.

Kjellström E, Feichter J, Hoffmann G. 2000. Transport of $\mathrm{SF}_{6}$ and ${ }^{14} \mathrm{CO}_{2}$ in the atmospheric general circulation model ECHAM. Tellus 52B:1-18. doi: 10.1034/j.1600-0889.2000.00882.x.

Koven CD, Riley WJ, Subin ZM, Tang JY, Torn MS, Collins WD, Bonan GB, Lawrence DM, Swenson SC. 2013. The effect of vertically resolved soil biogeochemistry and alternate soil $\mathrm{C}$ and $\mathrm{N}$ 
models on C dynamics of CLM4. Biogeosciences 10(11):7109-7131. doi: 10.5194/bg-10-7109-2013.

Kromer B, Münnich KO. 1992. $\mathrm{CO}_{2}$ gas proportional counting in radiocarbon dating-review and perspective. In: Taylor RE, Long A, Kra RS, editors. Radiocarbon after four decades. New York: Springer. p. 184-197.

Lerman J, Mook W, Vogel J. 1970. C14 in tree rings from different localities. In: Olsson IU, editor. Radiocarbon variations and absolute chronology. Proceedings, XII Nobel Symposium. New York: Wiley. p. 275-301.

Levin I, Hammer S. 2021. Supplementary data to Levin et al. (2021), Radiocarbon in global tropospheric carbon dioxide, ICOS-ERIC Carbon Portal. https://doi.org/10.18160/K6P6-WBH5.

Levin I, Hesshaimer V. 2000. Radiocarbon-a unique tracer of global carbon cycle dynamics. Radiocarbon 42:69-80. doi: 10.1017/S0033822200053066.

Levin I, Karstens U, Eritt M, Maier F, Arnold S, Rzesanke D, Hammer S, Ramonet $\mathrm{M}$, Vítková G, Conil S, Heliasz M, Kubistin D, Lindauer M. 2020. A dedicated flask sampling strategy developed for ICOS stations based on $\mathrm{CO}_{2}$ and $\mathrm{CO}$ measurements and STILT footprint modelling, Atmos. Chem. Phys. 20:11161-11180. doi: 10.5194/acp-20-11161-2020.

Levin I, Kromer B, Schmidt M, Sartorius H. 2003. A novel approach for independent budgeting of fossil fuels $\mathrm{CO}_{2}$ over Europe by ${ }^{14} \mathrm{CO}_{2}$ observations. Geophys. Res. Lett. 30(23):2194. doi: 10.1029/2003GL018477.

Levin I, Kromer B, Schoch-Fischer H, Bruns M, Münnich M, Berdau D, Vogel JC, Münnich KO. 1985. 25 years of tropospheric ${ }^{14} \mathrm{C}$ observations in central Europe. Radiocarbon 27:1-19. doi: 10. 1017/S0033822200006895.

Levin I, Kromer B, Wagenbach D, Münnich KO. 1987. Carbon isotope measurements of atmospheric $\mathrm{CO}_{2}$ at a coastal station in Antarctica. Tellus B 39B(1-2):89-95. doi: 10.1111/j.1600-0889. 1987.tb00273.x.

Levin I, Münnich KO, Weiss W. 1980. The effect of anthropogenic $\mathrm{CO}_{2}$ and ${ }^{14} \mathrm{C}$ sources on the distribution of ${ }^{14} \mathrm{CO}_{2}$ in the atmosphere. Radiocarbon 22:379-391. doi: 10.1017/S0033822 20000967X.

Levin I, Naegler T, Kromer B, Diehl M, Francey RJ, Gomez-Pelaez AJ, Steele LP, Wagenbach D, Weller R, Worthy DE. 2010. Observations and modelling of the global distribution and long-term trend of atmospheric ${ }^{14} \mathrm{CO}_{2}$. Tellus B 62(1):26-46. doi: 10.1111/j.1600-0889. 2009.00446.x.

Manning MR, Lowe DC, Melhuish WH, Sparks RJ, Wallace G, Brenninkmeijer CAM, McGill RC. 1990. The use of radiocarbon measurements in atmospheric studies. Radiocarbon 32(1): 37-58. doi: $10.1017 / \mathrm{S} 0033822200039941$.
Meijer HAJ, van der Plicht J, Gislefoss JS, Nydal R. 1995. Comparing long term atmospheric ${ }^{14} \mathrm{C}$ and ${ }^{3} \mathrm{H}$ records near Groningen, the Netherlands with Fruholmen, Norway and Izana, Canary Islands ${ }^{14} \mathrm{C}$ stations. Radiocarbon 37(1):39-50. doi: 10 . $1017 /$ S0033822200014776.

Miller JB, Lehman SJ, Montzka SA, Sweeney C, Miller BR, Karion A, Wolak C, Dlugokencky EJ, Southon J, Turnbull JC, Tans PP. 2012. Linking emissions of fossil fuel $\mathrm{CO}_{2}$ and other anthropogenic trace gases using atmospheric ${ }^{14} \mathrm{CO}_{2}$. J. Geophys. Res. 117:D08302. doi: 10.1029/2011JD017048.

Münnich KO. 1963. Der Kreislauf des Radiokohlenstoffs in der Natur. Naturwissenschaften 50(6):212-218.

Münnich KO, Vogel J. 1958. Durch Atomexplosionen erzeugter Radiokohlenstoff in der Atmosphäre. Naturwissenschaften 45(14):327-329.

Münnich KO, Vogel J. 1963. Investigations of meridional transport in the troposphere by means of radiocarbon measurements. In: Symposium on radioactive dating. Proc.: IAEA Vienna.

Naegler T, Levin I. 2006. Closing the global radiocarbon budget 1945-2005. J. Geophys. Res. 111:D12311. doi: 10.1029/2005JD006758.

Naegler T, Levin I. 2009. Biosphere-atmosphere gross carbon exchange flux and the $\delta^{13} \mathrm{CO}_{2}$ and $\Delta^{14} \mathrm{CO}_{2}$ disequilibria constrained by the biospheric excess radiocarbon inventory. J. Geophys. Res. 114:D17303. doi: 10.1029/2008JD011116.

Nakazawa T, Ishizawa M, Higuchi K, Trivett NBA. 1997. Two curve fitting methods applied to $\mathrm{CO}_{2}$ flask data. Environmetrics: The official journal of the International Environmetrics Society 8.3:197-218.

Nydal R, Lövseth K. 1983. Tracing bomb ${ }^{14} \mathrm{C}$ in the atmosphere 1962-1980. J. Geophys. Res. 88:3621-3642.

Nydal R, Lövseth K. 1996. Carbon-14 measurements in atmospheric $\mathrm{CO}_{2}$ from Northern and Southern Hemisphere sites, 1962-1993. ORNL/CDIAC-93, NDP-057. Carbon Dioxide Information Analysis Center, Oak Ridge National Laboratory, Oak Ridge, Tennessee. 67 p. doi: 10.3334/CDIAC/ atg.ndp057.

Rafter TA, Fergusson GJ. 1957. "Atom Bomb Effect"-recent increase of carbon-14 content of the atmosphere and biosphere. Science 126(3273):557-558.

Tans PP. 1981. A compilation of bomb ${ }^{14} \mathrm{C}$ data for use in global carbon model calculations. In: Bolin B, editor. SCOPE 16, carbon cycle modelling. Chichester, New York, Brisbane, Toronto: Wiley. p 131-157.

Telegadas K. 1971. The seasonal atmospheric distribution and inventories of excess carbon-14 from March 1955 to July 1969. HASL report 243, Health and Safety Lab., U.S. At. Energy Comm., New York. 
Turnbull JC, Miller JB, Lehman SJ, Tans PP, Sparks RJ, Southon J. 2006. Comparison of ${ }^{14} \mathrm{CO}_{2}, \mathrm{CO}$, and $\mathrm{SF}_{6}$ as tracers for recently added fossil fuel $\mathrm{CO}_{2}$ in the atmosphere and implications for biological $\mathrm{CO}_{2}$ exchange. Geophys. Res. Lett. 33:L01817. doi: 10.1029/2005GL024213.

Turnbull JC, Lehman SJ, Miller JB, Sparks RJ, Southon JR, Tans PP. 2007. A new high precision ${ }^{14} \mathrm{CO}_{2}$ time series for North American continental air. J. Geophys. Res. Atmos. 112(D11). doi: 10.1029/2006JD008184.

Turnbull J, Rayner P, Miller JB, Naegler T, Ciais P, Cozic A. 2009. On the use of ${ }^{14} \mathrm{CO}_{2}$ as a tracer for fossil fuel $\mathrm{CO}_{2}$ : quantifying uncertainties using an atmospheric transport model. J. Geophys. Res. 114(D22). doi: 10.1029/2009JD012308.

Turnbull JC, Mikaloff Fletcher SE, Ansell I, Brailsford GW, Moss RC, Norris MW, Steinkamp K. 2017. Sixty years of radiocarbon dioxide measurements at Wellington, New Zealand: 1954-2014. Atmos. Chem. Phys. 17:14771-14784. doi : 10.5194/acp-17-14771-2017.

Trumbore SE. 2009. Radiocarbon and soil carbon dynamics. Annual Review of Earth and Planetary Sciences 37:47-66. doi: 10.1146/annurev.earth.36. 031207.124300 .

UNFCCC. 2015. The Paris Agreement. http://unfccc. int/files/essential_background/convention/applica tion/pdf/english_paris_agreement.pdf.

Weller RI, Levin I, Wagenbach D, Minikin A. 2007. The air chemistry observatory at Neumayer stations $(\mathrm{GvN}$ and NH-II) Antarctica. Polarforschung 76(1-2):39-46.

Worthy DE et al. 2021. Results of a long-term international comparison of greenhouse gas and isotope measurements at the Global Atmosphere Watch (GAW) Station in Alert, Nunavut, Canada. In preparation. 